Wojciech Klag

\title{
CYWILIZACJA ŁACIŃSKA \\ W MYŚLI FELIKSA KONECZNEGO \\ (WYBRANE ZAGADNIENIA)
}

\section{GENEZA CYWILIZACJI ŁACIŃSKIEJ}

Profesor Feliks Koneczny ${ }^{1}$ uważał, że cywilizacja łacińska ${ }^{2}$ jest „[...] dalszym ciągiem rzymsko-helleńskiej [...]”3 cywilizacji opartej o religię chrześcijańską. Zatem korzenie tej cywilizacji sięgają czasów antycznych, wzbogaconych przez nowo powstałą religię ponad dwa tysiące lat temu. Cywilizacja ta opiera się na trzech filarach: klasycznej filozofii greckiej, tradycji prawa rzymskiego oraz religii chrześcijańskiej ${ }^{4}$.

${ }^{1}$ Feliks Koneczny był profesorem historii na Uniwersytecie w Wilnie na przełomie XIX i XX w. Jest twórcą oryginalnej koncepcji wielości cywilizacji.

2 „Cywilizacja łacińska” jest oryginalnym konstruktem F. Konecznego. Nikt poza nim nie określał tego terminu. U innych badaczy (np. A. Hickman) jest ona określana mianem „zachodnioeuropejskiej”.

${ }^{3}$ F. Koneczny, Polskie logos a ethos, Antyk, Komorów 1996, s. 9.

${ }^{4}$ Zob. J. Wilk, B. Walczak, Elementy aksjologii Unii Europejskiej, WAM, Kraków 2009, s. 14-21: „Najczęściej, gdy mówimy o fundamentach cywilizacji europejskiej, mamy na myśli: filozofię grecką, tradycję judeochrześcijańską i prawo rzymskie. Odpowiadają one trzem sferom: sferze rozumowej, duchowej i materialnej człowieka". 
Rozważając model cywilizacji łacińskiej ${ }^{5}$, autor sięga do korzenia, jakim był świat antyku, a więc Grecja i Rzym; poszukuje w nim fundamentów, na których później oparła się cywilizacja łacińska. Bada więc obecność qincunxa i trójprawa w cywilizacji grecko-rzymskiej. Starożytną Grecję uważa za odmienną cywilizacyjnie od Rzymu, pomimo przyjętej umownie jednolitości świata antycznego. Zgodnie z prawem dziejowym mówiącym o niemożliwości syntez cywilizacyjnych twierdzi, że cywilizacja hellenistyczna, mieszająca się z rzymską, doprowadziła w konsekwencji do ,[...] schyłku republiki rzymskiej i w okresie pryncypatu do zdominowania przez cywilizację niższą (hellenistyczność) cesarstwa rzymskiego, powodując jego upadek w $476^{\prime \prime}$.

${ }^{5}$ Tych samych źródeł cywilizacji łacińskiej co Koneczny doszukiwał się też A. Toynbee, pisał on mianowicie: „Stwierdziliśmy już, że nasza zachodnia społeczność (lub cywilizacja) jest usynowiona przez społeczność uprzednią. [...], Jakie właściwe oznaki takiego pokrewieństwa znaleźliśmy w przypadku usynowienia naszej własnej społeczności przez społeczność helleńską? Pierwszym z tych zjawisk było państwo uniwersalne (Cesarstwo Rzymskie), scalające całą społeczność helleńską w jedną polityczną wspólnotę w ostatniej fazie helleńskiej historii [...]. Z kolei po upadku Cesarstwa Rzymskiego nastąpiło pewnego rodzaju interregnum między zniknięciem społeczności helleńskiej a wyłonieniem się społeczności zachodniej. Interregnum to jest wypełnienie działalnością dwu instytucji: Kościoła chrześcijańskiego, utworzonego w łonie Cesarstwa i trwającego po jego upadku, oraz pewnej liczby efemerycznych państw sukcesyjnych, powstających na byłym terytorium Cesarstwa w ramach tzw. Volker-wanderung barbarzyńców z ziemi niczyjej poza granicami imperium. [...] W gruncie rzeczy Cesarstwo upadło, a Kościół przetrwał po prostu dlatego, że dawał on przewodnictwo i zjednywał lojalność, podczas gdy Cesarstwo od dawna nie zapewniało ani jednego, ani też drugiego. Tak więc Kościół, pozostałość po umierającej społeczności, stał się łonem, z którego we właściwym czasie narodziła się nowa społeczność". A. Toynbee, Studium historii, Państwowy Instytut Wydawniczy, Warszawa 2000, s. 29-30.

${ }^{6}$ A. Bokiej, Cywilizacja łacińska studium na podstawie dorobku historiozoficznego F. Konecznego, Atla 2, Legnica 2000, s. 62. 
Cywilizacja grecko-rzymska jako pierwszy fundament cywilizacji łacińskiej nie była jednolita, warto więc dla jej pełnego zobrazowania zaprezentować poszczególne elementy, które weszły później w skład cywilizacji łacińskiej. Autor twierdzi, że cywilizacja grecko-rzymska stanowiła jedność cywilizacyjną w dwóch kategoriach qincunxa, tj. prawdzie (nauce) oraz pięknie (sztuce), natomiast:

Zagadnienie cywilizacyjne Grecji i Rzymu bada [...], na trzech płaszczyznach; religijnej, społecznej i politycznej, starając się opisać różnice $\mathrm{w}$ odniesieniu do trzech kategorii qincunxa; „Dobra”, „Zdrowia” i „Dobrobytu”, [...] pomija przy tym kwestię dotyczące kategorii „Zdrowia”, a przecież były one w tamtym miejscu i czasie istotne, np. spartański ideał tężyzny fizycznej

Pomimo przyjęcia przez Rzymian wielu bóstw greckich, zasadnicza różnica pomiędzy religiami Grecji i Rzymu polegała na odmiennym postrzeganiu bóstwa. Rzymianie pojęcia abstrakcyjne jak np. Victoria, Nike traktowali jako bóstwa, natomiast Grecy każdemu bóstwu nadawali postać ludzką, co sprzyjało apoteozie ludzi. Z czasem w Grecji ukształtowały się zręby religii uniwersalnej, opartej o kult boga Apollina. Rzymianie natomiast mieli tendencję do ulegania synkretyzmowi religijnemu.

W dziedzinie społecznej zarówno przeciętni Grecy, jak i Rzymianie mieli prawo do udziału w życiu publicznym. Wspólnym elementem całego świata antycznego było oparcie zasad życia zbiorowego na dwóch wzorach: monogamii małżeńskiej oraz własności prywatnej, co wsparło później mocno chrześcijaństwo. Własność prywatna u Greków polegała na posiadaniu na własność

${ }^{7}$ Tamże, s. 63. 
czegokolwiek; dla Rzymian własność wiązała się przeważnie z posiadaniem ziemi na własne potrzeby.

W Cesarstwie Rzymskim posiadanie własności stałej (nieruchomej) implikowało obowiązek ochrony państwa przez posiadaczy ziemskich, co później zastosowano w cywilizacji łacińskiej. Panowała zasada, że ,[...] do służby wojskowej pociągano tylko właścicieli ziemskich, od drobnego chłopa do latyfundysty. Kto nie chciał służyć w wojsku musiał pozbywać się swojego gospodarstwa wiejskiego". W społeczności rzymskiej dokonywała się tzw. przemienność sił społecznych w realną silę polityczną; tę cechę społeczną zaczerpnęła później cywilizacja łacińska (w której społeczeństwo organizuje się militarnie w przypadku zagrożenia bytu państwa).

Zawiązkiem wszelkiej zbiorowości ludzkiej zawsze był ród, gdy dana zbiorowość wznosiła się na wyższy poziom rozwoju społecznego, zawsze wytwarzał się „[...] fundament prawa prywatnego, tj. prawo familijne, majątkowe i spadkowe. Im więcej różnic w ustroju rodów, tym większa rozmaitość w trójprawie" ${ }^{\text {". Brak }}$ jednolitego systemu trójprawa w cywilizacji greckiej determinowało wielość cywilizacyjną Grecji.

Prawodawstwo Drakona sankcjonujące w Grecji zemstę rodu (genos) $)^{10}$ oraz prawo Solona, które zakładało dziedziczenie majątku, doprowadziło do narzucenia praw wszystkim rodom w Grecji. Emancypacja rodu w rodzinę implikowała ,[...] emancypację syna spod władzy ojcowskiej - to co potem nazwano pełnoletniością, Ateny wyprzedziły w tym Rzymian" ${ }^{11}$. W Rzymie - jak twierdzi

\footnotetext{
${ }^{8}$ F. Koneczny, Cywilizacja bizantyńska, Komitet Wydawniczy, Londyn 1973, s. 34.

9 Tamże, s. 31.

${ }^{10}$ Podobnie jak w cywilizacji żydowskiej rodowe prawo zemsty.

${ }^{11}$ Tamże, s. 32.
} 
Koneczny - istniało jedno trójprawo dla wszystkich rodów. Jednolite trójprawo stanowiło dominująca cechę ekspansji Cesarstwa Rzymskiego.

Istotna różnica pomiędzy Grekami a Rzymianami polegała na odmiennym myśleniu prawniczym. „Grecja zaś okazywała skłonność do aprioryzmu prawniczego" ${ }^{12}$, dlatego tworzyli koncepcje idealnych ustrojów $w^{13}$, ciągle reformując państwa. Takie warunki nie sprzyjały wykształceniu się tzw. historyzmu narodowego ${ }^{14}$. Rzymianie natomiast byli zwolennikami myślenia aposteriorycznego; kultywowali obrzędy, byli przywiązani do ziemi, którą posiadali, czuli powinność do wszystkiego, co ich otaczało, w takich warunkach kształtowało się poczucie przynależności do narodu i wspólnoty historycznej. Dla genezy cywilizacji łacińskiej jest to istotne, ponieważ na najwyższym stopniu rozwoju cywilizacji, jak uważa profesor Koneczny, stoi właśnie naród.

Czynnikiem, który odegrał znaczącą rolę w tworzeniu się cywilizacji łacińskiej ${ }^{15}$, było niewątpliwie pojawienie się nowej religii -

${ }^{12}$ Tamże, s. 40.

${ }^{13}$ Koneczny ma tutaj na myśli trzy księgi Platona, w których filozof zawarł koncepcję idealnego państwa, były to Politea, Nomoi oraz Atlantis.

${ }^{14}$ Autor rozumie historyzm narodowy jako proces, dzięki któremu dokonał się swobodny rozwój społeczeństwa rzymskiego oraz poczucie wspólnoty społecznej (narodu).

${ }^{15}$ O korzeniach cywilizacji zachodu pisał C. Dawson: „Jeśli Europa zawdzięcza swe polityczne istnienie cesarstwu rzymskiemu, a swą duchową jedność Kościołowi katolickiemu, to co do kultury intelektualnej jest dłużna wobec trzeciego czynnika: tradycji klasycznej, który jest także jednym z podstawowych elementów, jakie złożyły się na utworzenie się jedności europejskiej. Jest w istocie rzeczą trudną zdać sobie sprawę z rozmiarów naszego długu, klasyczna tradycja bowiem stała się tak bardzo częścią kultury zachodniej, że nie jesteśmy już w pełni jej wpływu na naszą umysłowość. W całej historii Europy tradycja ta 
chrześcijaństwa, które w szczególności w płaszczyźnie moralnej (etycznej) ukonstytuowało uniwersalne wartości życia społecznego. Chrześcijaństwo, a w szczególności chrześcijaństwo zachodnie, czyli katolicyzm, za najwyższą normę uznało kategorię dobra, co umożliwiło budowanie społeczeństwa ${ }^{16}$ uniwersalnego opartego o zasadę solidarności, oraz ukształtowanie się personalistycznego podejścia do drugiego człowieka.

\section{STRUKTURA SPOŁECZNA}

Koneczny uważa, że struktura społeczna cywilizacji łacińskiej opiera się na rodzinie monogamicznej, która wykształciła się w cywilizacji rzymskiej, gdzie dokonała się emancypacja rodziny z rodu. Monogamia w cywilizacji łacińskiej jest dożywotnia. Zarówno mąż jak i żona posiadają równy status w małżeństwie; nie ma dominacji mężczyzny nad kobietą, jak to jest np. w cywilizacji arabskiej. W cywilizacji tej rodzina jako podstawowa komórka społeczna posiada pełną autonomię; nie jest skrępowana niczym, co ograniczałoby jej rozwój. Dzięki zdrowej rodzinie społeczeństwo może się rozwijać i wznosić na wyższe szczeble rozwoju cywilizacyjnego.

stanowiła stały fundament literatury i myśli zachodniej”. C. Dawidson, Tworzenie się Europy, PAX, Warszawa 1961, s. 75-97.

${ }^{16}$ Amerykański profesor S. Huntington prezentował podobne stanowisko w sprawie fundamentów cywilizacji łacińskiej, jednak cywilizację zachodniej Europy nazywał Cywilizacją Zachodu, nie „łacińską”. Według niego: „Cywilizacja Zachodu wyłoniła się w VIII i IX wieku n.e., przez następne stulecia kształtowały się jej szczególne cechy. Zaczęła się modernizować dopiero w wieku XVII i XVIII. Zachód był Zachodem na długo przedtem, zanim stał się nowoczesny. [...] Będąc cywilizacją trzeciej generacji, Zachód przejął wiele elementów od swych poprzedniczek, zwłaszcza cywilizacji klasycznej: grecką filozofię i racjonalizm, prawo rzymskie, język łaciński i chrześcijaństwo". S. Huntington, Zderzenie cywilizacji, Warszawskie Wydawnictwo Literackie MUZA SA, Warszawa 1997, s. 78-79. 
Etyka katolicka, na której oparte jest życie społeczne tej cywilizacji, niesie ze sobą cztery postulaty: ,„...] małżeństwo monogamiczne dożywotnie, dążenie do zniesienia niewolnictwa, zniesienie zemsty i przekazanie jej sądownictwu publicznemu, wreszcie niezawisłość Kościoła od władzy państwowej" ${ }^{17}$. Dlatego też w tej metodzie życia zbiorowego surowo zakazane są rozwody, niewolnictwo, wykorzystywanie drugiego, prostytucja, homoseksualizm, pedofilia i inne przypadki degeneracji moralnej. Wszelkie relacje w rodzinie muszą być oparte o zasady etyki katolickiej. Autor uważa, że za sprawą adaptacji prawa rzymskiego w cywilizacji łacińskiej zostały „[...] wyodrębnione sfery życia prywatnego i publicznego"18. Dzięki dualizmowi prawnemu, jak to określa Koneczny, społeczeństwo może harmonijnie się rozwijać.

Według krakowskiego myśliciela:

Cała filozofia religijna katolicyzmu i cała cywilizacja łacińska oparte są na personalizmie. [...] Jednostki, zrzeszając się do życia publicznego, natenczas tylko robią to prawdziwie, jeżeli działalność ta jest dobrowolna. Wtedy bowiem tylko formy tego życia stanowią prawdziwy wyraz woli danego zrzeszenia. A skoro zrzeszenie ma być tak urządzone, ażeby nie hamowało personalizmu, $[\ldots]$ nie może opierać się na jednostajności $[. . .]^{19}$.

Respektowanie przez cywilizację łacińską wolności i godności jednostki sprzyja poszanowaniu przez człowieka zasad etycznych i prawnych, obecnych w społeczeństwie oraz państwie, w którym

${ }^{17}$ F. Koneczny, O wielości cywilizacyj, WAM, Kraków 1997, s. 269.

${ }^{18}$ L. Gawor, O wielości cywilizacji. Filozofia społeczna Feliksa Konecznego, UMCS, Lublin 2002, s. 128.

${ }^{19}$ F. Koneczny, Kościót jako polityczny wychowawca narodów, [w:] Kościót a cywilizacje, red. F. Koneczny, ONION, Lublin 1996, s. 45-46. 
on żyje. Zasadniczo, z punktu widzenia stosunków społecznych personalistyczna cywilizacja łacińska:

\begin{abstract}
[...] chroni i umacnia wszelkie organiczne, naturalne formy organizacji społecznej i wszelkie przejawy indywidualnej twórczości i działalności, stawiając im tylko wymóg zgodności z etycznymi podstawami społeczeństwa. Dzięki temu w ramach cywilizacji rzymskiej, a później łacińskiej, powstało pojęcie jedności ponad różnorodnością - jedność pod względem zasadniczej treści etycznej, różnorodność pod względem form. W ogóle cywilizacja personalistyczna przywiązuje większą wagę do treści niż do formy ${ }^{20}$.
\end{abstract}

Cywilizacja łacińska jako jedyna położyła nacisk na wszechstronny rozwój kategorii prawdy. Kategoria prawdy jest nieodłącznie związana z kategorią dobra, dzięki której życie społeczne opiera się na zasadach etycznych, wyznawanych dobrowolnie przez społeczeństwo. Dzięki temu cywilizacja łacińska mogła jako jedyna z siedmiu istniejących cywilizacji - stać się cywilizacją personalistyczną, $\mathrm{w}$ przeciwieństwie do pozostałych zrzeszeń, będących cywilizacjami kolektywnymi.

Autonomiczna wola jednostki, poczucie własnej godności, nadrzędność etyki nad normami społecznymi sprzyja harmonijnemu rozwojowi jednostki społecznej. Profesor Koneczny uważa, że autonomiczna wola jednostki przejawia się w dążeniu do przyswajania religii bądź ideałów. Jeśli cywilizacja łacińska opiera się o system ideałów ważny dla danej społeczności, wówczas wykazuje zdolność do twórczego rozwoju wszelkich dziedzin życia zbiorowego. Uczony uważał, że tylko w cywilizacji łacińskiej realizuje

${ }^{20} \mathrm{~J}$. Kossecki, Podstawy nowoczesnej nauki porównawczej o cywilizacjach, Wydawnictwo Naukowe ,śląsk”, Katowice 2003, s. 103. 
się pełnia qincunxa, a wszechstronny rozwój osoby ludzkiej, przyczynia się do rozwoju gospodarczego społeczeństw tej cywilizacji ${ }^{21}$.

\section{RELIGIA}

Autor Cywilizacji żydowskiej uważa, że chrześcijaństwo pełni konstytutywną rolę w kształtowaniu cywilizacji łacińskiej. Jednak nie jest to chrześcijaństwo orientalne (które spełnia istotną rolę w budowaniu cywilizacji bizantyńskiej), ale chrześcijaństwo rzymskie, które oddziaływuje mocno na społeczność zachodnio-europejską.

$\mathrm{Z}$ qiuncunxa bytu ziemskiego, uwzględniona jest w ewangeliach jedna tylko kategoria, ale ta starczy na wszystko, od urządzenia sobie dnia powszedniego aż do urządzeń państwowych. Jakoby płaszczem, otula ewangelią i ochrania wszystko kategorią Dobra, moralnością, etyką ${ }^{22}$.

Katolicyzm wprowadza więc Dobro ${ }^{23}$ jako kategorię duchową, która jest jednym $\mathrm{z}$ fundamentów personalizmu. Etyka w tym

${ }^{21} \mathrm{~F}$. Koneczny uważał, że katolicyzm sprzyjał bogaceniu się narodów cywilizacji łacińskiej. Jest to zasadne spostrzeżenie, jednak w większym stopniu protestantyzm doprowadził do bogacenia się Zachodniej Europy, dzięki apoteozie pracy i czasu. „Protestancka afirmacja pracy pociągnęła za sobą radykalne przewartościowanie innych form aktywności, z separacją zakonów włącznie. Życie ludzkie - jak nauczali purytanie - jest niezwykle krótkie i cenne zarazem; należy więc każdą jego cząstkę wykorzystać ku chwale Bożej i własnemu zbawieniu. [...] Protestantyzm był religią czynu opartą na afirmacji świata. Cechował go wrogi stosunek do monastycyzmu, mistycyzmu i kontemplacji, a także silny nacisk na moralny obowiązek nieustannego ulepszenia zastanej rzeczywistości": A. Flis, Chrześcijaństwo i Europa, Zakład Wydawniczy „Nomos”, Kraków 2001, s. 360-362.

${ }^{22}$ F. Koneczny, O wielości..., s. 265.

${ }^{23}$ Zapisuję z wielkiej litery poszczególne kategorie qincunxa, ponieważ taką metodę stosuje profesor Koneczny. 
typie cywilizacyjnym jest etyką katolicką, wyprowadzaną bezpośrednio z nakazów Ewangelii.

Katolicyzm $^{24}$ jako religia kreacjonistyczna, a nie emanacyjna ${ }^{25}$, umożliwiał rozwój aktywności ludzkiej; sprzyjał rozwojowi nauki (np. zakładanie przez zakony katolickie uniwersytetów, na których uczono filozofii, prawa, teologii, medycyny, astronomii i kultury); nie ograniczał swobodnego rozwoju nauk przepisami religijnymi - jak choćby w cywilizacji żydowskiej za sprawą przepisów Tory i Talmudu; czy w cywilizacji arabskiej za sprawą Koranu. Autor Praw dziejowych uważa, że dzięki zniesieniu przez Kościół Rzymskokatolicki prawa do zemsty, w społeczności wytwarzała się powoli państwowość, dlatego „nie ma tedy czynnika bardziej państwowotwórczego jak Kościół katolicki”26.

Uczony zawsze cenił wyżej katolicyzm niż inne religie czy wyznania chrześcijańskie.

${ }^{24}$ Według A. Frątczak: „Metoda personalistyczna oparta na kreacjonizmie wyklucza natomiast fatalizm. Przesądza o tym rozpoznanie wartości jednostki jako osoby obdarzonej wolną wolą, jednostki samodzielnej. W cywilizacji personalistycznej zatem (a taka jest tylko jedna - łacińska) teoretycznie każdy człowiek bierze na siebie odpowiedzialność za losy «zrzeszenia, społeczności i państwa». Tak pojęty personalizm, będący wytworem teologii katolickiej, pełni w teorii Konecznego funkcję wzorca, idealnego punktu odniesienia do badań porównawczych nad religiami”. A. Frątczak, Feliks Koneczny o państwie i wartościach, Ośrodek Myśli Politycznej, Księgarnia Akademicka, Kraków 2003, s. 84.

${ }^{25}$ Autor Praw dziejowych doszukuje się wątków emanacyjnych w judaizmie, islamie, buddyzmie, hinduizmie. Emanatyzm polega na kolektywnym kontakcie z Bogiem, bóstwem, a nie osobowym, jak to jest tylko w katolicyzmie. Koneczny uważa, że emanatyzm nie sprzyja aktywności społecznej, ponieważ jednostka jest wtłoczona w kolektyw (na płaszczyźnie religijnej); nie jest uwzględniona indywidualność człowieka, co sprzyja biernej postawie życiowej osób żyjących w kolektywnym modelu społecznym.

${ }^{26}$ A. Frątczak, Feliks..., s. 271. 
Wyższość katolicyzmu polega zaś między innymi na tym, że nie cofając się przed zaangażowaniem w sprawy społeczne i państwowe, rozstrzyga on zarazem kwestię zwierzchnictwa jednego z dwóch zasadniczych systemów sił dziejowych: siły materialne podporządkowuje silom duchowym. Próby organizowania niektórych sił duchowych historiozof dostrzegał wprawdzie już w czasach przedchrześcijańskich (nauka, sztuka), ale nie miał też wątpliwości, że po raz pierwszy w historii wszystkie siły duchowe zostały zorganizowane dopiero przez Kościół katolicki ${ }^{27}$.

Według profesora Konecznego dopiero w cywilizacji łacińskiej dzięki katolicyzmowi dokonała się supremacja pierwiastka duchowego nad materialnym ${ }^{28}$.

\section{ETYKA, PRAWO, POLITYKA}

Autor Rozwoju moralności uważa, że każda cywilizacja ma swoją etykę. Według niego etyka stanowi integralną część metody współżycia społecznego. Uczony uważa, że nie istnieje jedna etyka

${ }^{27}$ S. Bukowska, Filozofia polska wobec problemu cywilizacji teoria Feliksa Konecznego, Wydawnictwo Uniwersytetu Śląskiego, Katowice 2007, s. 114.

${ }^{28}$ O konstytutywnej roli religii chrześcijańskiej w kształtowaniu elementów cywilizacyjnych Zachodniej Europy, również o funkcji państwowotwórczej pisał C. Dawson: „Początki kultury zachodniej znajdujemy w nowej wspólnocie duchowej, która powstała na ruinach imperium rzymskiego dzięki nawróceniu północnych barbarzyńców na wiarę chrześcijańską. Kościół chrześcijański odziedziczył tradycję rzymskiego imperium. Przyszedł do barbarzyńców jako przedstawiciel wyższej cywilizacji, wyposażony w prestiż i powagę prawa rzymskiego. Załamanie się politycznej organizacji cesarstwa rzymskiego pozostawiło wielką próżnię, której nie mógł wypełnić żaden barbarzyński król czy dowódca; została ona wypełniona przez Kościół, spełniający rolę nauczyciela i prawodawcy nowych narodów. Łacińscy Ojcowie Kościoła - Ambroży, Augustyn, Leon i Grzegorz Wielki - byli w rzeczywistym tego słowa znaczeniu ojcami kultury zachodniej [...]". C. Dawson, Religia i powstanie kultury zachodniej, PAX, Warszawa 1958, s. 26-27. 
uniwersalna, wspólna dla wszystkich cywilizacji, można tylko doszukiwać się wspólnych „norm umysłowych”, które są obecne w każdym systemie etycznym, tylko że każdy inaczej je interpretuje. Te wspólne normy to: „[...] obowiązek, bezinteresowność, odpowiedzialność, sprawiedliwość, sumienie, tudzież stosunek do pracy i do czasu, ujmowane wszędzie w jakiś sposób. Są to generalia etyki" ${ }^{29}$. Natomiast etyka obecna w życiu zbiorowym cywilizacji łacińskiej pochodzi od religii katolickiej. „Albowiem cywilizacja łacińska nie tworzyła nowej etyki, lecz katolicką przyjęła za swoją. [...]. Cywilizacja łacińska nie jest bezetyczna, nie jest amoralna [...]"30. Uczony, podkreślając istotną rolę etyki katolickiej w łacińskiej „metodzie życia ustroju zbiorowego”, zwraca uwage na konstytutywne zadanie etyki katolickiej w kształtowaniu społeczeństwa. „Etyka cywilizacji łacińskiej jest etyką katolicką, bo cywilizacja ta jest dziełem Kościoła, składa się z narodów wychowywanych przez Kościół"31.

Etyka może obejmować życie społeczne, rodzinne, państwowe, narodowe w zależności od cywilizacji. Etyka w cywilizacji łacińskiej jest totalna, to znaczy obejmuje wszystkie elementy życia zbiorowego człowieka.

Nieustanne ograniczanie się wymogami etyki bez wątpienia wystawia cywilizację łacińską na ryzyko wyparcia tej metody nie przebierając w środkach: bizantyńską, turańską, żydowską. W każdej chwili może bowiem okazać się, że cywilizowanym z łacińska

${ }^{29}$ F. Koneczny, Harmider etyk, [w:] O cywilizację łacińska, red. F. Koneczny, ONION, Gliwice 1996, s. 39.

${ }^{30}$ F. Koneczny, Państwo i prawo, WAM, Kraków 1997, s. 101.

${ }^{31}$ F. Koneczny, O ład $w$ historii, MICHALINEUM, Warszawa 1991, s. 61. 
ludziom zabraknie sił i determinacji by wieść życie zorganizowane na tak wysokim poziomie ${ }^{32}$.

Koneczny uważa, że etyka katolicka stawia bardzo wysokie wymagania osobom egzystującym w cywilizacji łacińskiej, ale dzięki temu można osiągnąć wyższy poziom rozwoju człowieczeństwa. Etyka motywuje jednostkę do aktywności i pracy nad sobą. Jednak nie jest łatwo osiągnąć rozwój osobowy, jaki panuje w łacińskiej „metodzie życia zbiorowego”. „Trojaka jest jednakże walka o byt: materialna, moralna i umysłowa. Tylko zwierzę prowadzi samą jedynie materialną. Czy nie najcięższa bywa walka o byt moralny, pośród ciągłych pokus? Niektórzy wychodzą z niej już za młodu zwyciężeni"33. Etyka katolicka jest uniwersalna: traktuje równo członków cywilizacji łacińskiej jak i członków innych form ustroju życia zbiorowego, w opozycji do dualistycznej etyki żydowskiej.

Teoretyk cywilizacji jest zdania, że w życiu moralnym każdej jednostki ludzkiej istotne jest powiązanie rozumu z systemem etycznym $^{34}$. Rozum bowiem kieruje postępowaniem człowieka, analizuje, co jest dobre a co złe, sądy intelektualne determinują dobrą bądź złą działalność ludzką. Uczony uważa, że zasady etyczne cywilizacji łacińskiej obejmują zarówno sferę prywatną, jak i publiczną. Osoba żyjąca w cywilizacji łacińskiej powinna stosować zasady etyki katolickiej również w życiu publicznym. „Dla

32 P. Bezat, Poglady polityczno-prawne Feliksa Konecznego, Dom Wydawniczy „Ostoja”, Krzeszowice 2004, s. 40-41.

${ }^{33}$ F. Koneczny, Rozwój moralności, Antyk, Komorów 1997, s. 94.

${ }^{34} \mathrm{Na}$ zależność między rozumem a systemem etycznym (katolickim) zwrócił także uwagę Jan Paweł II w swojej encyklice Fides et ratio. Uważa on mianowicie, że dzięki współpracy rozumu z wiarą (którą posiada system etyczny) człowiek wznosi się na najwyższy poziom moralny oraz zbliża się do Boga. 
katolika nie ma dwóch etyk, nie ma dwóch katechizmów. Nie można trzymać się kilku etyk jednocześnie. Przy harmiderze etyk nie da się zrobić nic pozytywnego" ${ }^{35}$. Tak więc etyka posiada w cywilizacji łacińskiej pozycję uprzywilejowaną. Wszystkie inne kategorie winny być podporządkowane zasadom etycznym. Człowiek „łaciński” musi być człowiekiem moralnym, istotne jest w ,[...] jego koncepcji pojęcie ideału, do którego wszyscy powinni dążyć, podwyższając wciąż poprzeczkę dla swoich poczynań. Wiąże się to również z rozwojem etyk ${ }^{36}$ zawodowych" $^{37}$. Dążenie jednostki do perfekcjonizmu etycznego sprzyja doskonaleniu się społeczeństwa i jego postępowi.

Prawo w teorii wielości cywilizacji Konecznego pełni ważną rolę. Nie ma cywilizacji, w której nie byłoby prawa. „Rozsądek powiada, że w każdym zrzeszeniu muszą być jakieś prawa, bo inaczej nic się nie utrzyma" ${ }^{38}$. Dla uczonego prawo stanowi system zakazów i nakazów, które należy egzekwować w społeczeń-

${ }^{35}$ F. Koneczny, Prawa dziejowe, Antyk, Komorów 1997, s. 66-67.

${ }^{36}$ „Określenie «etyka chrześcijańska» nie jest terminem powszechnie jednoznacznie rozumianym. Niekiedy bywa on używany w sensie teologicznym jako katolicka, na autorytecie Pisma Świętego i Nauczającego Kościoła oparta, nauka o moralności ludzkiego działania. [...] system filozoficzny zakorzeniony w scholastyczno-tomistycznej tradycji, który mimo długiej historii stanowi nadal twórczą doktrynę etyczno-społeczną. [...] Współczesna etyka chrześcijańska tkwi korzeniami w tomistycznej doktrynie moralnej, wobec tego zrąb głoszonych przez tę etykę najogólniejszych zasad i szczegółowych normatywów (ocen oraz nakazów) utożsamia się ogólnie mówiąc ze znaną nam już filozoficzną myślą św. Tomasza i późniejszych tej myśli kontynuatorów w osobach - przykładowo mówiąc - Suareza [...]”. T. Ślipko, Historia etyki, PETRUS, Kraków 2010, s. 141.

${ }^{37} \mathrm{P}$. Grabowiec, Model spoleczeństwa obywatelskiego w historiozofii Feliksa Konecznego, Wydawnictwo Uniwersytetu Wrocławskiego, Wrocław 2000, s. 48.

${ }^{38}$ F. Koneczny, Państwo a metody życia zbiorowego, [w:] O cywilizację łacińska, red. F. Koneczny, Dom Wydawniczy „Ostoja”, Krzeszowice 2006, s. 15. 
stwie. Wymienia on dwa ${ }^{39}$ źródła prawa: etykę lub władzę. Uczony uważa, że etyka w pierwotnych zrzeszeniach ludzkich spełniała funkcje prawną, dopiero pod wpływem rozchwiania zasad panujących w pierwotnym ustroju życia zbiorowego rozpoczął się proces separowania prawa od zasad etycznych.

Autor Praw dziejowych wyróżnia dwa rodzaje praw: prawo wyłonione i narzucone.

Pierwsze pozostaje $\mathrm{w}$ zgodzie $\mathrm{z}$ aksjologicznymi podstawami metody zorganizowania wspólnoty, w której ma obowiązywać, drugiemu natomiast brak tego przymiotu. Zachowanie współmierności zależy głównie od treści prawa, choć nieraz wystarcza legitymizacja jego pochodzenia- istnieją bowiem cywilizacje, wedle których posłuszeństwo wobec uznawanej władzy stanowi najwyższy wymóg etyki ${ }^{40}$.

Badacz sądzi, że prawo może powstawać na dwa różnorakie sposoby: apriorycznie oraz aposteriorycznie. Koneczny jednoznacznie opowiadał się za aposteriorycznym ${ }^{41}$, a nie apriorycznym sposobem tworzenia prawa. Uważał, że w łacińskiej „metodzie życia zbiorowego" prawo wyłania się aposteriorycznie, w zgodności z etyka katolicką. Cechą etyki katolickiej jest stawianie coraz to nowych wymagań społeczeństwu, co implikuje konieczność nieustannego dostosowywania prawa do zmieniają-

${ }^{39}$ W Rozwoju moralności przedstawia też Koneczny trzecie źródło prawa, a mianowicie przemoc. Pojawia się ona w sytuacji, gdy silniejszy dominuje nad słabszym i narzuca mu swoje zasady.

${ }^{40}$ P. Bezat, Poglady...., s. 12.

${ }^{41}$ Teoretyk cywilizacji za aposterioryczny sposób tworzenia prawa rozumie, prawo które powstaje przez analizę empiryczną faktów, wnioski które wyprowadzono stanowią materiał do tworzenia paragrafów dotyczących np. prawa cywilnego. 
cej się rzeczywistości, by sprostać wymogom etyki łacińskiej. Prawo w cywilizacji łacińskiej winno zawsze czerpać z etyki, $\mathrm{w}$ przeciwnym wypadku istnieje zagrożenie, że w imię prawa można uczynić wszystko, nawet popełnić zbrodnie, które dopuszcza prawo (np. aborcję czy eutanazję).

Uczony podkreśla, że prawo pełni wobec etyki rolę wtórną i służebną. Celem prawa w cywilizacji łacińskiej jest dążyć do dobra jednostki, społeczności, państwa oraz narodu. Uczony sprzeciwia się negatywnej postawie wobec prawa, którą określa terminem blu mizm. Polega ona na wykorzystywaniu prawa dla własnych potrzeb za pomocą kruczków prawnych; sytuacja taka nie może mieć miejsca w wysoce etycznej cywilizacji łacińskiej. Aby prawo mogło być egzekwowane w zbiorowości, potrzebny jest urząd sędziego, który stoi na straży prawa oraz przeciwstawia się wszelkim przejawom blumizmu. Sędzia taki musi być wysoce etyczny, czyli powinien kierować się sumieniem rozumianym jako autokrytyka moralna. Sędzia nie może być tylko „maszynką" do stosowania paragrafów, lecz musi mieć możliwość decydowania o ich słuszności. Stosowanie zasad etycznych w prawie implikuje to, że wymiar sprawiedliwości będzie bardziej ludzki. Prawo w ujęciu Konecznego nie jest wartością samą w sobie, lecz tylko narzędziem mającym umożliwić regulowanie stosunków społecznych. Prawo bez etyki jest tylko bezdusznym mechanizmem. Tworzenie prawa oraz jego egzekucja powinny według opierać się o zasady etyki katolickiej.

Według teoretyka cywilizacji istnieją trzy systemy regulujące relacje pomiędzy prawem prywatnym i publicznym: monizm prawa prywatnego, monizm prawa publicznego oraz dualizm prawa.

Dualizm prawny stanowi cechę cywilizacji łacińskiej, stanowi dla nas dogmat cywilizacyjny. Monizm prawny [...] tworzy kontrast 
i tej cywilizacji i zarazem etyki katolickiej. Jest nieprzyjacielem tedy Kościoła i narodów przez Kościół „wychowywanych”. Jeżeli nie mamy zginąć, musimy zadbać o zachowanie dualizmu prawnego ${ }^{42}$.

Cywilizacja łacińska nie jest oparta na monizmie prawa prywatnego, ponieważ nastąpiła w niej emancypacja rodziny, a monizm prawa prywatnego występuje w cywilizacjach, gdzie życie społeczne oparte jest o model rodowy. Według Konecznego monizm prawa prywatnego obecny jest w cywilizacjach: turańskiej, arabskiej i chińskiej.

Prawo w tych trzech cywilizacjach jest kontynuacją rozwiązań charakterystycznych dla prawa $\mathrm{w}$ rodzie. $\mathrm{W}$ tych cywilizacjach prawo publiczne to rozbudowane prawo prywatne ${ }^{43}$.

Życie zbiorowe cywilizacji łacińskiej nie funkcjonuje też w oparciu o monizm prawa publicznego, występujący w cywilizacji bizantyńskiej. Prawo prywatne jest zmarginalizowane $\mathrm{w}$ tym modelu ustroju życia zbiorowego na rzecz prawa publicznego. Prawo publiczne przejmuje kompetencje prawa prywatnego. Monistyczne prawo publiczne w konsekwencji prowadzi do omnipotencji państwa.

Jak społeczeństwo istniało w Bizancjum o tyle tylko, o ile cesarz (tj. biurokracja) zezwolił, tak też prawo prywatne było wciąż osłabiane i podważane przez prawo państwowe, czyli nazywając rzecz po imieniu, znów przez biurokracje $e^{44}$.

${ }^{42}$ F. Koneczny, Rodowód monizmu prawnego, [w:] O cywilizację łacińska, red. F. Koneczny, Dom Wydawniczy „Ostoja”, Krzeszowice 2006, s. 51-52.

${ }^{43}$ W. Szurgot, Prawo jako fundament cywilizacji łacińskiej w myśli Feliksa Konecznego, Dom Wydawniczy „Ostoja”, Krzeszowice 2007, s. 53.

${ }^{44}$ F. Koneczny, Różne typy cywilizacji, Dom Wydawniczy „Ostoja”, Krzeszowice 2005, s. 23. 
Prawo publiczne jest aprioryczne, nie jest dostosowane do potrzeb obywateli, lecz państwa. Nie ma także odniesień do zasad etyki chrześcijańskiej. Monizm prawa publicznego zagraża funkcjonowaniu cywilizacji łacińskiej, ponieważ niesie ze sobą model społeczny, w którym obywatele muszą poddać się prawu, które reguluje wszystkie płaszczyzny życia zbiorowego, oraz zgodzić się na coraz większą rozbudowę prawa publicznego, co sprzyja bierności społecznej.

Przede wszystkim źródło choroby tkwi w przekonaniu powszechnym o wszechmocy i koniecznej wszędzie obecności państwa. Elephantiasis państwowości, tj. urządzeń państwowych [...] $]^{45}$.

Dla naukowca najdoskonalszy system prawny występuje tylko w cywilizacji łacińskiej, w której istnieje współmierność pomiędzy prawem prywatnym a publicznym. Jak już wcześniej wspomniałem, dualizm ten wytworzył się najwcześniej w starożytnym Cesarstwie Rzymskim. Dzięki dualizmowi prawniczemu członkowie cywilizacji łacińskiej mogą swobodnie funkcjonować, bez nadmiernych ograniczeń prawa publicznego. Obywatelowi państwa pozostawia się możliwość rozwoju, który implikuje rozwój państwa. Prawo prywatne dotyczy wszystkich spraw życia ludzkiego, natomiast prawo publiczne określa obszar działalności administracji. Według Konecznego tylko w społeczności opartej o personalizm a nie kolektywizm może ukształtować się taki model prawa jak w cywilizacji łacińskiej i jej kulturach. Prawo rzymskie, które zanikło po upadku cesarstwa, Kościół rzymskokatolicki przechował i wykorzystał do budowania zrębów cywilizacji łaciń-

${ }^{45} \mathrm{~F}$. Koneczny, Elephantiasis prawodawcza, [w:] Obronić cywilizację łacińska, red. F. Koneczny, Fundacja Rozwoju Kultury Polskiej, Lublin 2002, s. 202. 
skiej. Dzięki dualizmowi prawnemu i etyce katolickiej cywilizacja ta mogła osiągnąć najwyższy stopień rozwoju.

Teoretyk cywilizacji uważa, że cywilizacja determinuje także politykę.

Ludzkie działanie społeczne, potocznie nazywane polityką, wiążą się i bazują na całokształcie spraw ludzkich, tj. bazują na cywilizacji, która to preferuje i posiada sobie właściwą wizję człowieka, hierarchię dobra, prawa i urządzeń społecznych. Stąd też wypływa wniosek, że cywilizacja $\mathrm{w}$ istotny sposób determinuje cywilizację $e^{46}$.

Zastanawiając się, jak ma wyglądać polityka w cywilizacji łacińskiej, uczony dochodzi do wniosku, że do sfery życia publicznego należy wprowadzić etykę katolicką. Dostrzegając różnorakie patologie i upadek obyczajów autor szuka sposobów, w jaki można im zaradzić. Postuluje następujące rozwiązanie: „Stawiam wymagania jak najskromniejsze. Upraszam o niewiele, bo tylko o przestrzeganie dziesięciorga przykazań" ${ }^{47}$.

Warto przedstawić, jak prawa dekalogu Koneczny rozciąga na płaszczyznę polityczną.

Pierwsze prawo brzmi: „Nie będziesz miał bogów cudzych przede mną”. „Pragniemy, żeby samo piastowanie władzy w naszym państwie opierało się na miłości Bożej. Rządzić, władać, organizować, należy w imię Boże" ${ }^{48}$. Ateista czy innowierca nie może piastować urzędów państwowych w cywilizacji łacińskiej,

${ }^{46}$ P. Skrzydlewski, Polityka w cywilizacji łacińskiej, Fundacja Rozwoju Kultury Polskiej, Lublin 2002, s. 36.

\footnotetext{
${ }^{47}$ F. Koneczny, Państwo i prawo..., s. 101.

${ }^{48}$ Tamże, s. 103.
} 
ponieważ obca mu jest etyka i wiara katolicka. Tylko wierzący katolicy powinni reprezentować władzę państwową w zbiorowościach typu łacińskiego. Stosowanie w życiu zasad etyki katolickiej jest gwarantem rozwoju cywilizacyjnego. Odstępstwo od wiary katolickiej grozi upadkiem cywilizacyjnym, dlatego członkowie tej cywilizacji powinni domagać się, by wiara katolicka nie była marginalizowana $\mathrm{w}$ życiu publicznym. Profesor uważa, że tylko etyka katolicka jest gwarantem zdrowego życia społecznego; wszelkie próby stosowania różnych systemów wartości grożą katastrofą cywilizacyjną, bo przecież nie można być cywilizowanym na dwa sposoby.

Drugie prawo brzmi: „Nie wzywaj imienia Bożego nadaremno". Prawo to mówi, aby nie angażować zbytnio Kościoła katolickiego w sferę życia politycznego. Na tym polega wielkość cywilizacji łacińskiej, że Kościół i państwo są bytami autonomicznymi. Gdy jednak zdarzają się przypadki upadku moralności i szyderstwa z etyki katolickiej, należy stanowczo reagować.

Trzecie prawo mówi: „Pamiętaj, abyś dzień święty święcił”. Państwo w cywilizacji łacińskiej winno respektować uczucia religijne swych obywateli. Dniem świętym w cywilizacji łacińskiej jest niedziela i państwo powinno uznać, że jest to dzień przeznaczony na udział w nabożeństwach i odpoczynek po całotygodniowej pracy. Zagrożeń dla trzeciego przykazania Koneczny upatrywał przede wszystkim w coraz silniejszym ruchu socjalistycznym, który starał się redukować nauczanie Kościoła katolickiego.

Czwarte prawo mówi: „Czcij ojca i matkę swoją” - zgodnie z tym przykazaniem rodzinie, osobom piastującym władzę oraz zmarłym należy się szacunek, ponieważ stanowią jedną wspólnotę ducha narodowego (Polacy, Rosjanie, Włosi). 
Węzłem niezniszczalnym związani jesteśmy z przodkami; dźwigamy bowiem po nich dziedzictwo, bez względu na to czy miłe czy niemiłe ze wszystkim złem i dobrem. Rodzi się z tego historyzm, tj. poczucie że jest się narodem historycznym. Bez historyzmu nie ma miłości Ojczyzny, która stanowi najwyższą ewolucję i koronę IV przykazania9 ${ }^{49}$.

Piąte prawo brzmi: „Nie zabijaj”, a stosować to prawo jest świętym obowiązkiem człowieka. Państwo nie może godzić się na rozwiązania, które umożliwiałyby zabijanie innych ludzi. W cywilizacji łacińskiej życie człowieka jest bezcenne, dlatego należy je chronić, a osoby chore otoczyć opieką. Policja winna zaś ścigać przestępców, a nie parać się intryganctwem politycznym. W cywilizacji łacińskiej każdy przypadek zamachu na ludzkie życie (morderstwo, aborcja, eutanazja) winien spotkać się z surową karą, gdyż etyka katolicka nie może godzić się na przypadki lekceważenia życia ludzkiego.

Szóste przykazanie Dekalogu mówi: „Nie cudzołóż”. Małżeństwo w cywilizacji łacińskiej jest monogamiczne, mężczyzna i kobieta poprzez ślub stają się instytucją publiczną, dodatkowo uświęconą przez Kościół katolicki. Małżeństwo powinno mieć zapewnioną ochronę prawną, ponieważ w łacińskim „ustroju życia zbiorowego" jest monogamią dożywotnią. Osoba, która po zawarciu związku małżeńskiego zmienia męża lub żonę na kogoś innego dopuszcza się profanacji i porzucenia cywilizacji łacińskiej.

Wszyscy rozwodnicy, zmieniający wyznanie dla zmiany kobiety, porzucają tym samym cywilizację łacińską, ponieważ w tej cywilizacji nie można $\mathrm{w}$ żaden sposób mieć drugiej żony za życia pierwszej. Polsce zaś nie można być pożytecznym poza cywiliza-

${ }^{49}$ F. Koneczny, Państwo i prawo..., s. 115. 
cją łacińską; nie powinno się przeto osobom takim powierzać funkcji ${ }^{50}$ publicznych ${ }^{51}$.

Państwo winno stwarzać warunki ekonomiczne, by rodzina mogła się rozwijać - brak pracy zmusza do emigracji, co nie sprzyja małżeństwu.

Kwestię szóstego przykazania związane są wielce ze sprawą dobrobytu, albowiem przestałoby się plenić niejedno zło społeczne i wróciłoby do równowagi wiele stosunków, gdyby mężczyźni mogli się żenić młodo. Kobieta na ogół w zasadzie nie powinna zarabiać poza domem. [...] dopóki każdy 28 letni mężczyzna nie będzie mógł ustalić się i być pewnym, że przy rządności nie zabraknie mu nigdy środków na utrzymanie rodziny ${ }^{52}$.

Profesor Koneczny stanowczo sprzeciwia się także pornografii, uważając to zjawisko za wielkie zło, które wpływa destrukcyjnie na człowieka, dlatego usprawiedliwia wprowadzenie cenzury przez państwo na takie treści. Pornografia wynika jego zdaniem z „mieszanek” cywilizacyjnych.

Siódme przykazanie mówi: „Nie kradnij”. Uczony uważa każdą kradzież - zgodnie z nauką Kościoła katolickiego - za zło, któremu należy się przeciwstawić w życiu publicznym. Państwo nie może

${ }^{50}$ Koneczny jako sympatyk endecji wytyka partii rządzącej i jej przewodniczącemu Piłsudzkiemu, że naczelnik kraju niegodnie sprawował urząd, ponieważ rozbił swoje małżeństwo przez związek z inną kobietą. Chodzi o głośny romans ,[...] Józefa Piłsudskiego z «piękną Marią», Marią z Koplewskich Juszkiewiczową, rozwódką i w dodatku ewangeliczką, dla której Piłsudski zmienił wyznanie rzymskokatolickie na ewangelicko-augsburskie i wziął cichy ślub w kościółku protestanckim pod Łomżą". M. Bębenek., Paradygmat polityki w cywilizacji łacińskiej, [w:] Feliks Koneczny dzisiaj, red. J. Skoczyński, Księgarnia Akademicka, Kraków 2000, s. 88.

${ }^{51}$ F. Koneczny, Państwo i prawo..., s. 121.

${ }^{52}$ Tamże, s. 122. 
okradać swoich obywateli. Władza polityczna w państwie cywilizacji łacińskiej nie może być jak władza bizantyńska, w której sam władca decyduje o tym, co jest dobre, a co złe, lecz winna respektować prawo do własności prywatnej i do jej poszanowania.

Ósme przykazanie brzmi: „Nie mów przeciw bliźniemu twemu fałszywego świadectwa" - według uczonego szerzenie nieprawdy jest nieuczciwością oraz grzechem. Życie publiczne winno opierać się na fundamencie prawdy. Władza państwowa powinna być oparta na zasadach etyki katolickiej, nie może więc używać kłamliwej propagandy oraz politycznej cenzury. Nie może też utrzymywać tajnej policji infiltrującej społeczeństwo. Według Konecznego kultywowanie prawdy sprzyja poczuciu bezpieczeństwa i stałości w państwie. Prawda może się realizować jedynie w personalizmie, wymaga od człowieka wysokiego rozwoju etycznego. Prawda winna być obecna we wszelkich dziedzinach życia zbiorowego; również nauka, by się rozwijać, musi się opierać na prawdzie.

Ostatnie dwa przykazania łączy uczony w jedno: „Nie pożądaj żony bliźniego twego; ani osła, ani wołu, ani żadnej rzeczy, która jego jest". Przykazania te są - według profesora - powtórzeniem szóstego i siódmego prawa. Ostrzega jednak przed czymś, o czym nie było wcześniej mowy, a mianowicie przed pożądaniem władzy. Ludzie dążący do władzy pod płaszczykiem wartości chrześcijańskich obiecują to, co jest ważne dla wspólnoty, po wyborach szybko zapominają jednak o swoich obietnicach. Badacz sprzeciwia się takiemu instrumentalnemu uprawiania polityki, która przecież już dla starożytnych była Greków „roztropną troską o dobro wspólne".

Według Konecznego, doktryna katolicka nakłada na każde działanie człowieka obowiązek kierowania się w swoim postępowaniu miłością do Boga i człowieka. Dlatego piastujący władzę w winni w swoim postępowaniu kierować się miłością do Boga 
i człowieka, ponieważ dobro człowieka jest głównym celem państwa w cywilizacji łacińskiej.

Koncepcja polityki według profesora Konecznego winna opierać się na zasadach etyki katolickiej, która dzięki stawianiu najwyższych wymagań umożliwia wszechstronny rozwój jednostki, społeczeństwa, narodu, a w konsekwencji państwa. Osoby sprawujące władzę w państwach cywilizacji łacińskiej nie mogą zapominać, że głównym celem tych państw jest przede wszystkim dobro osoby.

To właśnie dobro, rozumiane jako cel, stało się w cywilizacji łacińskiej, personalistycznej, czynnikiem charakteryzującym tę cywilizację [...]. Oczywiście, musimy mieć świadomość, że Prawda i Dobro najwyższe są Bogiem, ku któremu prowadzi wiara odsłaniająca perspektywy życia osobowego człowieka i łacińskiej cywilizacji ${ }^{53}$.

Koncepcja życia publicznego, którą kreśli uczony, jest bardzo piękna, lecz niestety nie do zrealizowania, ponieważ nie ma możliwości, by tylko katolicy mieli prawo uczestniczyć w życiu publicznym oraz sprawować władzę. Zakrawałoby to co najmniej na marginalizację osób innego wyznania. Zasadna jest uwaga, by władza postępowała etycznie, ponieważ jej rolą ma być służba obywatelom, a nie ich wyzyskiwanie. Trzeba się jednak z uczonym zgodzić, że Kościół katolicki winien stanowić pewien fundament społeczeństwa, narodu oraz państwa, ponieważ nauka, którą głosi, posiada charakter uniwersalny i umożliwia ludziom żyjącym w cywilizacji łacińskiej wszechstronny rozwój etyczno-społeczno-duchowy. Życie konkretnego człowieka, które jest oparte o normy moralne, może przynieść tylko same plusy dla sfery publicznej.

${ }^{53}$ M.A. Krąpiec, Państwo jako rozumny ład dobra, [w:] Człowiek $w$ kulturze, red. P. Jaroszyński, KUL, Lublin 1998, s. 12. 


\section{ATRYBUTY CYWILIZACJI ŁACIŃSKIEJ}

Badając fenomen cywilizacji uczony dochodzi do wniosku, że pośród wielości cywilizacji, które od wieków są obecne w świecie, tak naprawdę jedna tylko cywilizacja wzniosła się ponad wszystkie pozostałe, tą „metodą” najwyżej cenioną jest przez niego cywilizacja łacińska. Cywilizację łacińską jako jedyną uznaje za pełną, czyli taką, która jest wewnętrznie zintegrowana.

Pełnia cywilizacji polega na tem, że społeczeństwo posiada taki ustrój życia zbiorowego, prywatnego (tj. rodzinnego) i publicznego, społecznego i państwowego, takie urządzenia materialne, tudzież taki system moralno-intelektualny, iż wszystkie dziedziny życia, uczuć, myśli i czynów tworzą zestroje o jednolitym umiarze, konsekwentne w zespole swych idei i czynów ${ }^{54}$.

Cywilizację łacińską cenił badacz także ze względu na to, że jako jedyna uwzględnia wszystkie kategorie qincunxa, oraz że jest personalistyczna i zachodzi w niej supremacja sił duchowych nad fizycznymi. Tylko w cywilizacji łacińskiej pojawia się dominacja prawa naturalnego nad prawem stanowionym. Profesor Koneczny uważa cywilizację łacińską za najwyższą, ponieważ tylko w niej zrzeszenie społeczne osiąga najwyższy stopień rozwoju, jakim jest naród. Życie społeczne opiera się na dialogu, a nie na sile, jak to ma miejsce w cywilizacji bizantyńskiej. Bardzo istotnym wyznacznikiem wartości łacińskiego „urządzenia życia zbiorowego” jest autonomia między Kościołem katolickim a państwem, dzięki czemu sfera życia publicznego nie jest zdominowana przez sakralizm, jak w innych cywilizacjach np. żydowskiej.

${ }^{54}$ Tamże, s. 155. 
Najważniejszą cechą cywilizacji łacińskiej jest prymat wolności człowieka i związana z tym możliwość osobowego rozwoju jednostki ludzkiej.

A istnieje tylko jedna cywilizacja niegromadna, personalistyczna; jest nią cywilizacja łacińska, w której człowiek jest uznany za byt osobowy, a przez to samo akceptowany, jako samodzielnie istniejący podmiot, samoświadomy, mający własne cele, wolny. Jest podmiotem, a nie tylko przedmiotem praw (zarówno w sensie ius jaki i lex) oraz jest celem działań społecznych, co zwykło się nazywać „godnością" osoby. Warta szczególnego przypomnienia jest przede wszystkim sprawa wolności osobistej, wykluczającej tortury, zniewolenie, bezprawne aresztowanie, gwarantującej „prywatność”55; warta podkreślenia jest też sprawa podmiotowości prawa oraz ludzkiej godnośćs6.

Koneczny uważał, że tylko wolny człowiek, kierujący się dobrem drugiego i miłością do Boga może tworzyć na mocnych fundamentach naród i państwo oraz z nadzieją spoglądać w przyszłość. Trudno nie zgodzić się z tym spostrzeżeniem krakowskiego profesora.

${ }^{55}$ Trzeba podkreślić, że to cywilizacja łacińska wygenerowała Powszechną Deklarację Praw Człowieka i Obywatela. Dokument ten gwarantuje powszechne prawa człowieka każdemu bez względu na status materialny i społeczny, pochodzenie, przekonania religijne. Uzasadniona wydaje się zatem apoteoza tego typu cywilizacji przez Konecznego.

${ }^{56}$ M.A. Krąpiec, O ludzka politykę, Gutenberg Print, Warszawa 1996, s. 303. 


\title{
LATIN CIVILIZATION IN THOUGHT OF FELIX KONECZNY (SELECTED ISSUES)
}

\begin{abstract}
SUMMARY
The subject of the article is to present the theory of Latin civilization by Felix Koneczny. The ancient civilization components such as: Greek philosophy, Roman law, and Christian religion were highlighted. The Model is based on the Latin civilization of Catholic ethics that covers all spheres of social life. The most important foundation of social structure in this civilization is family. The grandeur of this civilization lies in the dominance of the spiritual over the material. It is also important personal nature of civilization. The implementation of the principles of the Catholic Church is the best way to the fullness of human development and society in the state apparatus.
\end{abstract}

KEYWORDS

Latin civilization, law, ethics, religion 